\title{
Effects of water dynamics on Zostera marina: transplantation experiments in the intertidal Dutch Wadden Sea
}

\author{
M. M. van Katwijk* , D. C. R. Hermus \\ Department of Aquatic Ecology and Environmental Biology, University of Nijmegen, Toernooiveld 1, 6525 ED Nijmegen, \\ The Netherlands
}

\begin{abstract}
Pilot experiments in the tidally dominated Dutch Wadden Sea indicated a negative relationship between Zostera marina L. transplantation success and tidal depths. As light availability was sufficient, we hypothesised that water dynamics (particularly waves) and ensuing sediment mobility (movement or resuspension of the sediment) were the major cause for the loss of transplants at larger depths. Transplantation experiments were carried out at intertidal flats and depths under conditions of normal and reduced water dynamics and sediment mobility, using exclosures that reduced water dynamics and shells that stabilised the sediment. To test bioturbation effects, cages that excluded large biota were used. Without protection, Z. marina plants were successfully established in a belt within the intertidal zone ( 0 to $-0.20 \mathrm{~m}$ mean sea level, MSL) at 2 out of 3 transplantation sites during the first growing season. Reduced water dynamics by exclosures prevented the loss of plants in the zone -0.40 to $-1.15 \mathrm{~m} \mathrm{MSL}$; removal of the exclosures after 1 mo resulted in loss of all plants within a few days. Neither light limitation nor bioturbation could explain these results. We conclude that prevalent water dynamics, particularly the relative period of exposure to wave dynamics, were too high for establishment and maintenance of intertidal $Z$. marina at depths below $-0.20 \mathrm{~m}$ MSL at these sites of intermediate exposure. At the third, exposed, transplantation site, water dynamics prevented transplantation success along the entire depth gradient studied. Reduction of sediment mobility by shells had a positive effect on transplant survival, particularly at $-0.20 \mathrm{~m}$ MSL. Shell armour can therefore be recommended in transplantations near the lower limit of potential intertidal habitats of $Z$. marina. Anchorage of the plants with pegs had no positive effect. Depth limitation of intertidal $Z$. marina populations by water dynamics can explain zonation patterns that occur in several tidal systems in northwest Europe.
\end{abstract}

KEY WORDS: Bioturbation · Eelgrass · Exclosures · Germination $\cdot$ Hydrodynamics $\cdot$ Restoration · Sediment mobility $\cdot$ Seedling survival $\cdot$ Zonation

\section{Resale or republication not permitted without written consent of the publisher}

\section{INTRODUCTION}

The economical and ecological importance of seagrass beds is widely acknowledged and the worldwide losses of seagrass beds during recent decennia have led to numerous restoration and mitigation projects. The Wadden Sea in northwest Europe, one of

*E-mail: mvkatwyk@sci.kun.nl the world's largest international marine wetlands, lost at least $150 \mathrm{~km}^{2}$ Zostera marina L. (eelgrass) during the last century (den Hartog \& Polderman 1975, Reise et al. 1989). Lack of recovery has been attributed to increased turbidity and increased fisheries activities (Giesen et al. 1990, de Jonge \& de Jong 1992). Recently, turbidity has decreased and fisheries activities have been forbidden in some areas (e.g. van Katwijk et al. 1998, 2000). Restoration of the $Z$. marina biotope in the Dutch Wadden Sea is regarded as one of the 
major ecological targets of Dutch government policy (Anonymous 1989).

Pilot transplantation experiments in the Dutch Wadden Sea along a depth gradient revealed that transplants vanished within $3 \mathrm{wk}$ below a depth of $-0.20 \mathrm{~m}$ below mean sea level (MSL) (van Katwijk 1993, van Katwijk \& Schmitz 1993). At present, irradiance in the Dutch Wadden Sea should be sufficient to sustain Zostera marina to at least $-0.45 \mathrm{~m}$ MSL (the effect of tides was included in the calculation of this depth: see van Katwijk 1992), and the quality of Wadden Sea water does allow growth of $Z$. marina (van Katwijk et al. 1998). In the Wadden Sea, average wave action at the sediment surface (orbital velocity $\mathrm{m} \mathrm{s}^{-1}$ ) increases with depth down to just below mean low tide (Hermus 1995, van Katwijk et al. 2000). Therefore, we hypothesise that water dynamics, particularly wave action, and the ensuing sediment mobility (movement and/or resuspension of the sediment) in the intertidal flats of the Wadden Sea are too severe for eelgrass establishment at depths greater than $-0.20 \mathrm{~m}$ MSL. This hypothesis is supported by a frequently observed zonation pattern of $Z$. marina in northwest Europe, particularly at the beginning of the twentieth century. At sheltered locations, the intertidal eelgrass beds protruded to greater depths and joined with the subtidal eelgrass zone, whereas at less sheltered locations, the mid-intertidal eelgrass beds were separated from the subtidal beds by an unvegetated zone. Depth limitation of the mid-intertidal zone could not have been caused by light limitation, as can be inferred from the presence of the subtidal beds. Depth limitation by increasing water dynamics, on the other hand, would offer a logical explanation (van Katwijk et al. 2000, and also 'Discussion' of present paper).

To our knowledge, the effects of water dynamics and sediment mobility on Zostera marina transplantations have never been tested, although the importance of these factors to seagrasses is indicated by the inverse correlations of seagrass cover with hydrodynamics (e.g. Fonseca \& Bell 1998) and with sedimentation and erosion processes (e.g. Boley 1988), as well as by results of mesocosm and laboratory studies (Watanabe \& Terawaki 1986, Koch 1999). On the other hand, stagnancy does have a negative effect on seagrass productivity and biomass (Fonseca \& Kenworthy 1987, Koch 1999). However, stagnancy does not occur in the Wadden Sea. Semi-diurnal tides, with tidal amplitudes varying between 1.36 and $3.73 \mathrm{~m}$, ensure continuous water movement (Postma \& Dijkema 1982).

Bioturbation is an unlikely cause of the disappearance of the transplanted eelgrass in the pilot experiment. Bird predation would have resulted in high losses in the higher zones where the emergence period is longest, and would decrease with depth, but this is the opposite of the pattern observed. Also, observa- tions indicated minimal bird predation during the growth season (Hermus 1995). Arenicola marina is the main bioturbator in the Wadden Sea; however, it was never observed in densities that might have been damaging to Zostera marina transplantations (authors' pers. obs.). Adult green crabs Carcinus maenas, which damage eelgrass transplants when present in densities higher than 1 ind. $\mathrm{m}^{-2}$ (Davis et al. 1998), are only present in much lower densities than this in intertidal areas of the Wadden Sea (van der Veer et al. 1998, Dittmann \& Villbrandt 1999). Rays, potentially damaging to eelgrass transplantations (Fonseca et al. 1994), are nowadays absent from the Wadden Sea (Lozán et al. 1994, Rijnsdorp et al. 1996). Most of the other sediment-disturbing animals (e.g. flatfishes) are only abundant as juveniles, which are unable to destroy seagrass plants (H. Asmus, R. M. Asmus \& K. Reise pers. comm.).

In the present study, the effects of water dynamics and sediment mobility on Zostera marina were tested by means of transplantation experiments along depth gradients in the Wadden Sea, using shell armouring, pegs and exclosures. Part of the pilot experiment was repeated to assess year-to-year differences. Exclosures with different tops were used to test the effect of water dynamics and the exclusion of potentially bioturbating organisms.

\section{METHODS}

Three transplantation experiments with Zostera marina L. were carried out in the Dutch Wadden Sea (Figs. 1 \& 2). In all experiments, the bare root-transplantation method was employed (Davis \& Short 1997). The donor population was mainly annual (van Katwijk et al. 1998).

In the first experiment, the effect of depth gradient and sediment stabilisation was tested. Part of the experiment was similar to a previous transplantation experiment (van Katwijk \& Schmitz 1993), in order to assess year-to-year differences. The experiment began in June 1993 and was carried out at 3 sites (Fig. 1) over a depth gradient of +0.15 to $-0.90 \mathrm{~m} \mathrm{MSL}$, on untreated and shell-armoured sediments (Fig. 2a). A control transplantation was carried out at the donor site (De Plaat, Terschelling) to test the effect of transplanting. At 2 out of 3 locations (Balgzand and Wierschuur: Fig. 1) Zostera marina was present until the 1970s in the midintertidal zone (den Hartog \& van der Velde 1970, den Hartog \& Polderman 1975, Dijkema 1989). Near the third location ('t Horntje) Z. marina was present until the 1930s (Oudemans et al. 1870, den Hartog \& Polderman 1975), and was located near a deep channel (Fig. 1). As a consequence, exposure to water dynamics (e.g. breaking waves) was high in comparison to the other 2 sites. 


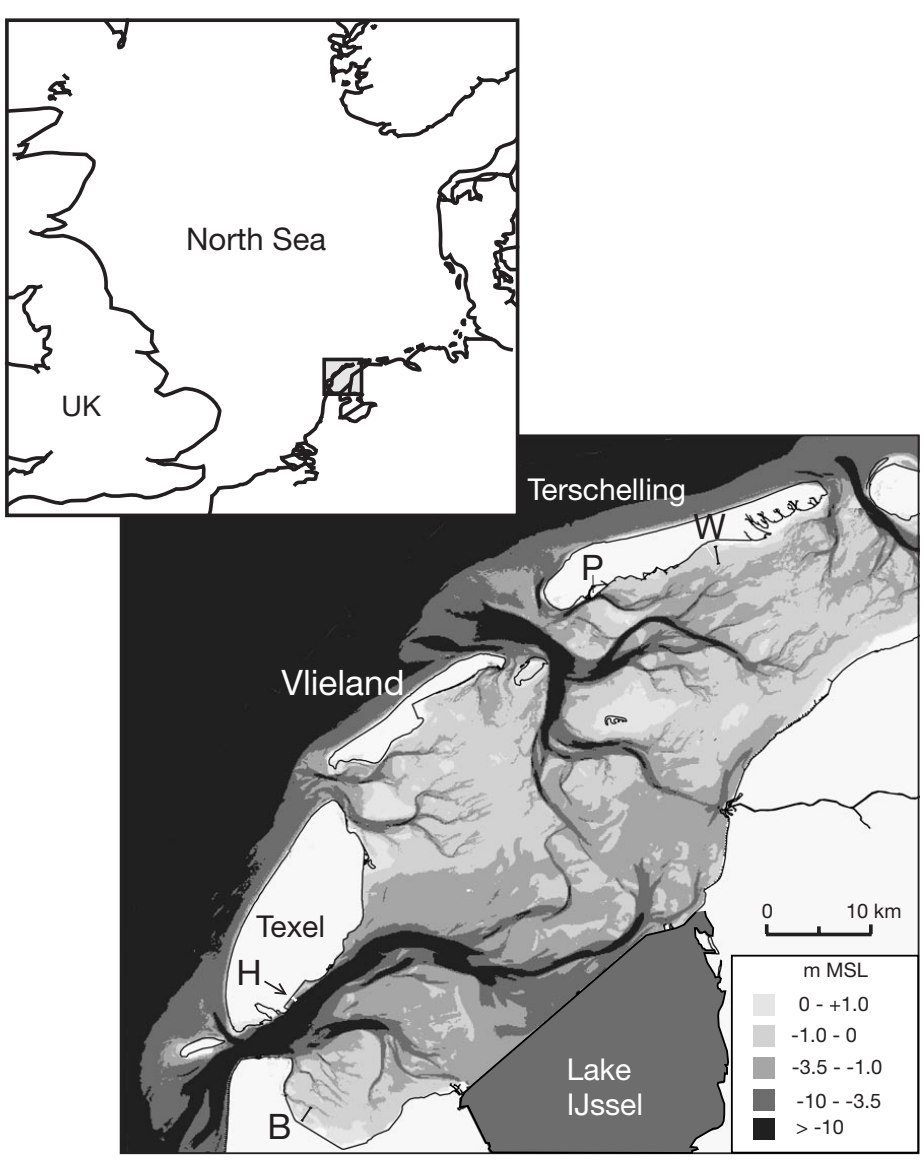

Fig. 1. Dutch Wadden Sea with its complex bathymetry. $\mathrm{P}=$ location of Zostera marina donor population De Plaat; $\mathrm{W}, \mathrm{B}, \mathrm{H}=$ transplantation sites Wierschuur (W), Balgzand (B) and 't Horntje $(\mathrm{H})$ in transects adjacent to the islands, all located in the Dutch Wadden Sea. Tidal amplitudes: P and W, $1.80 \mathrm{~m} ; \mathrm{B}$ and $\mathrm{H}, 1.40 \mathrm{~m}$. MSL = mean sea level

Table 1 and Fig. 3 summarise the main hydrodynamic features of the transplantation sites at different tidal depths.

In the second experiment, plexiglass-topped exclosures and shell armouring of the sediment were used to test the effect of water dynamics in comparison to the effect of sediment stabilisation and no treatment (Fig. 2b). The experiment began in June 1993 at Wierschuur over a depth range of 0 to $-0.60 \mathrm{~m} \mathrm{MSL}$. The exclosures lessened wave activity to $80-100 \%$ (H. J. Verhagen pers. comm.), but still allowed free exchange of water. To test the effect of water dynamics on established plants, the exclosures were removed after 1 mo (Watanabe \& Terawaki 1986). Water dynamics consist of wave action and tidal currents. Wave action is depth-related, it increases towards just below the low tide level (between 0.10 and $0.30 \mathrm{~m}$ below low tide) and decreases with increasing depth (van Katwijk et al. 2000, and present Fig. 3). Orbital velocity generated by waves is expected to have a much larger (traction) effect on seagrass shoots compared to current velocity, as wave action results in constant flapping movements of the plants, in contrast to the single bending of the plants in currents. Therefore, and because the tidal current velocities above tidal flats are low (0 to $0.15 \mathrm{~m} \mathrm{~s}^{-1}$ ) (Postma 1961, Asmus \& Asmus 1991), tidal currents are not considered in this study.

A third experiment was performed in July 1993 at Wierschuur at $-0.60 \mathrm{~m}$ MSL to test the effect of water dynamics with the exclusion of bioturbating organisms, using plexiglass-topped, gauze-topped and open exclosures representing large (80 to $100 \%$ ), intermediate (40 to $50 \%$ ) and very slight ( 0 to $5 \%$ ) water dynamics (H. J. Verhagen pers. comm.) (Fig. 2c). It was assumed (and later confirmed by observations during the experiment) that large animals such as crabs and juvenile flatfishes did not enter the open exclosures (H. Asmus, R. M. Asmus \& K. Reise pers. comm.). The effect of water dynamics over a depth range of -0.60 to $-1.15 \mathrm{~m} \mathrm{MSL}$ was also tested in this experiment, using the plexiglass-topped exclosures. The effect of peg anchoring on the transplantation success of Zostera marina was tested over a depth gradient of -0.20 to $-1.15 \mathrm{~m}$ MSL.

Transplantation. Zostera marina plants for Expts 1 and 2 were collected and rinsed with seawater at the donor site De Plaat, Terschelling, on the first $2 \mathrm{~d}$ of June 1993, and transplanted to 3 transplantation sites and the donor site (Fig. 1). The plants were transported and kept in boxes with a shallow layer of seawater at a temperature of 10 to $15^{\circ} \mathrm{C}$ for $1 \mathrm{~d}$. In Expt 1 and the control transplantation at the donor site, a planting unit (PU) consisted of 36 shoots (4 replicates per depth); in Expts 2 and 3, a PU consisted of 9 shoots (2 and 4 replicates per depth, respectively: Fig. 2). Peg-anchored PUs consisted of 3 shoots attached in a bundle to 3 pegs (peg length $=0.22 \mathrm{~m}$ ). All PUs were planted at least $7 \mathrm{~m}$ apart. Each shoot consisted of a rhizome segment with 1 shoot.

Shell armouring was achieved by mixing a $5 \mathrm{~cm}$ layer of shells (mainly cockles) with local sediment, which was subsequently spread and compacted over the plot. The exclosures consisted of a wooden frame of $0.4 \times 0.4 \times$ $0.3 \mathrm{~m}$ with the sides covered with $1 \mathrm{~mm}$ plastic gauze to allow free exchange of water. The exclosures were anchored by iron plates pressed into the sediment on 2 sides. The top of the exclosures was sealed with either plexiglass or $1 \mathrm{~mm}$ gauze, or the tops remained open.

At -0.40 and $-0.60 \mathrm{~m} \mathrm{MSL}$, diatoms were cleaned from the plexiglass covering of the exclosures during every monitoring event (at least monthly during the growing season, see following subsection). This was not necessary at $0.0 \mathrm{~m}$ MSL. The exclosures were removed after 1 mo.

Monitoring. In Expts 1 and 2, the Zostera marina transplants at Wierschuur were monitored once every 


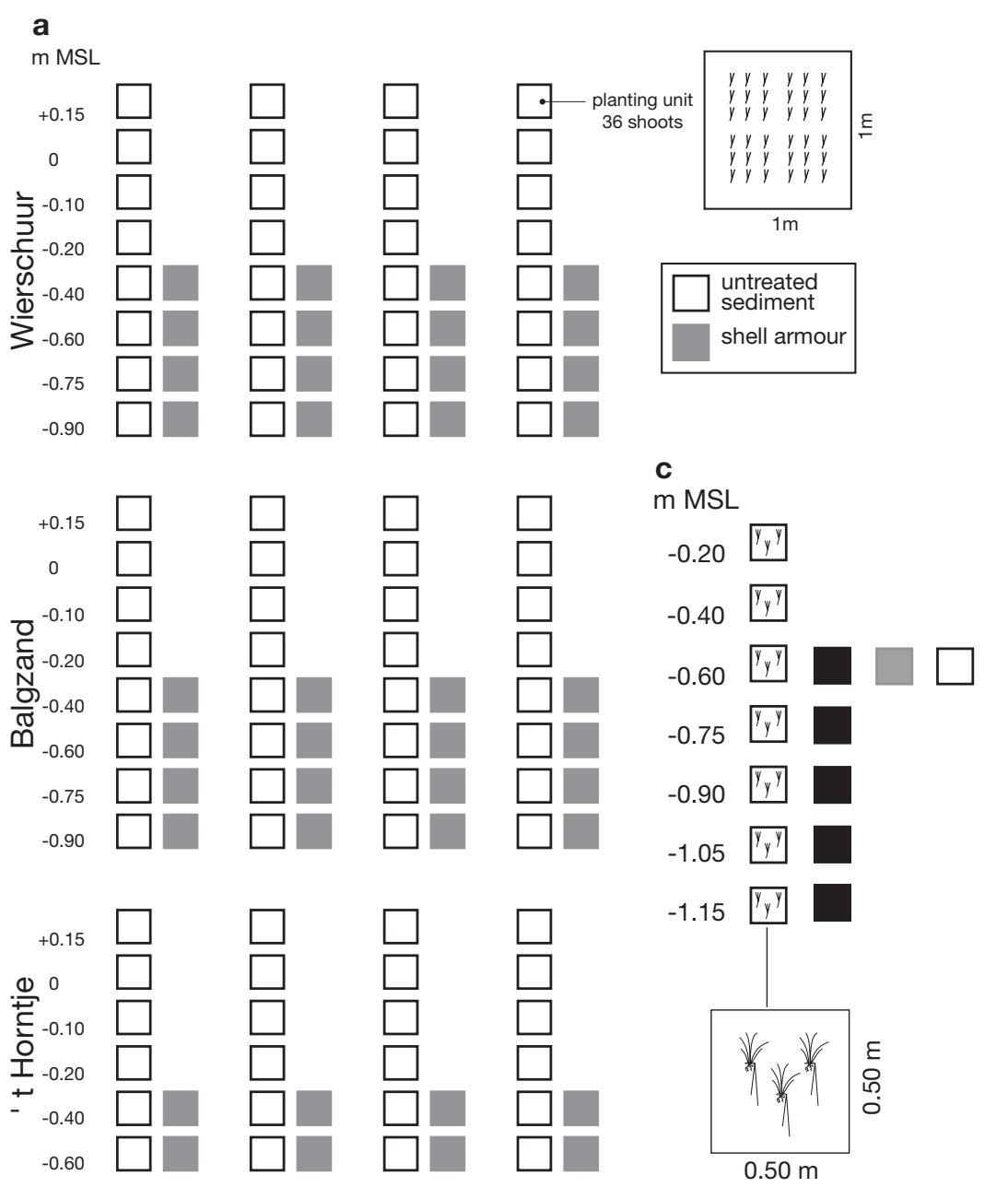

b

m MSL
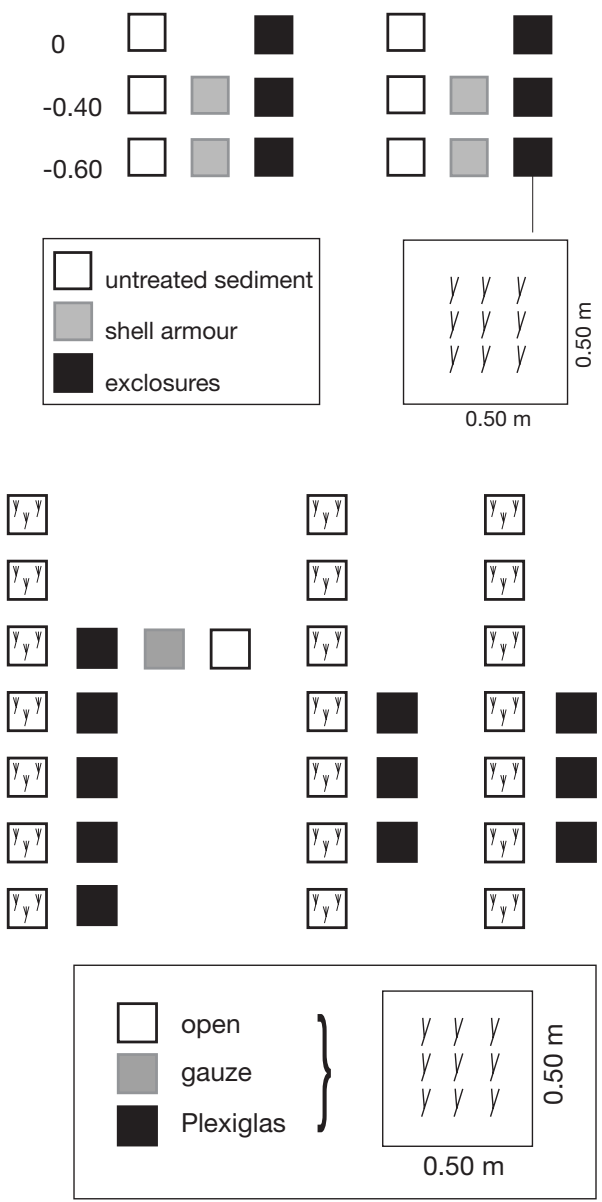

Fig. 2. Zostera marina. Experimental set-up of (a) Expt 1, (b) Expt 2 and (c) Expt 3. Peg-anchored shoots were bundled into threes

$2 \mathrm{~d}$ during the first $2 \mathrm{wk}$; the monitoring was then gradually reduced to once a week. From the second half of September monitoring occurred monthly. Balgzand and 't Horntje were monitored weekly during the establishment phase. After $4 \mathrm{wk}$, monitoring was reduced to once or twice a month. In autumn, no monitoring occurred, while we monitored monthly from December to April. Expt 3 was monitored weekly. The peg-an- chored transplants were monitored a further 5 times during the first $3 \mathrm{wk}$ of the experiment.

Vegetative and generative shoots were counted. New shoots were recorded as such when the distance to the parental plant was $>2 \mathrm{~cm}$. The length of 15 randomly chosen eelgrass shoots (the longest leaf + sheath) was measured after 1 and $4 \mathrm{wk}$, at Wierschuur (Expts 1 and 2), the donor site transplantation and the natural donor

Table 1. Hydrodynamic characteristics of the 3 transplantation sites in 1993 between June 2 and August 31. Only days with a fetch of $>0.5 \mathrm{~km}$ were included. $a=$ tidal amplitude $(\mathrm{m}) ; \mathrm{n}=$ number of days with fetch $>0.5 \mathrm{~km}$ (total $=91 \mathrm{~d}) ; U_{\max }=$ mean, SD (within parentheses), and maximum (in italics) (over this period) of the maximal orbital velocity at sediment surface (m s $\mathrm{s}^{-1}$ ) are presented; $H_{\mathrm{s}}=$ wave height $(\mathrm{m})$ and $T=$ wave period (s) during tidal cycle. $U_{\max }$ did not vary over depth gradient studied, except where indicated

\begin{tabular}{|c|c|c|c|c|c|}
\hline Site & $a$ & $\mathrm{n}$ & $U_{\max }$ & $H_{\mathrm{s}}$ & $T$ \\
\hline Wierschuur & 1.90 & 53 & $0.42(0.065) 0.54$ & $0.15(0.030) 0.24$ & $1.57(0.263) 2.03$ \\
\hline Balgzand & $1.40^{\mathrm{a}}$ & 27 & $0.35(0.044) 0.43$ & $0.37(0.155) 0.65$ & $2.27(0.531) 3.11$ \\
\hline 't Horntje & $1.40^{\mathrm{a}}$ & 47 & $0.63(0.145) 0.85^{\mathrm{b}}$ & $0.21(0.052) 0.33$ & $1.88(0.389) 2.71$ \\
\hline
\end{tabular}




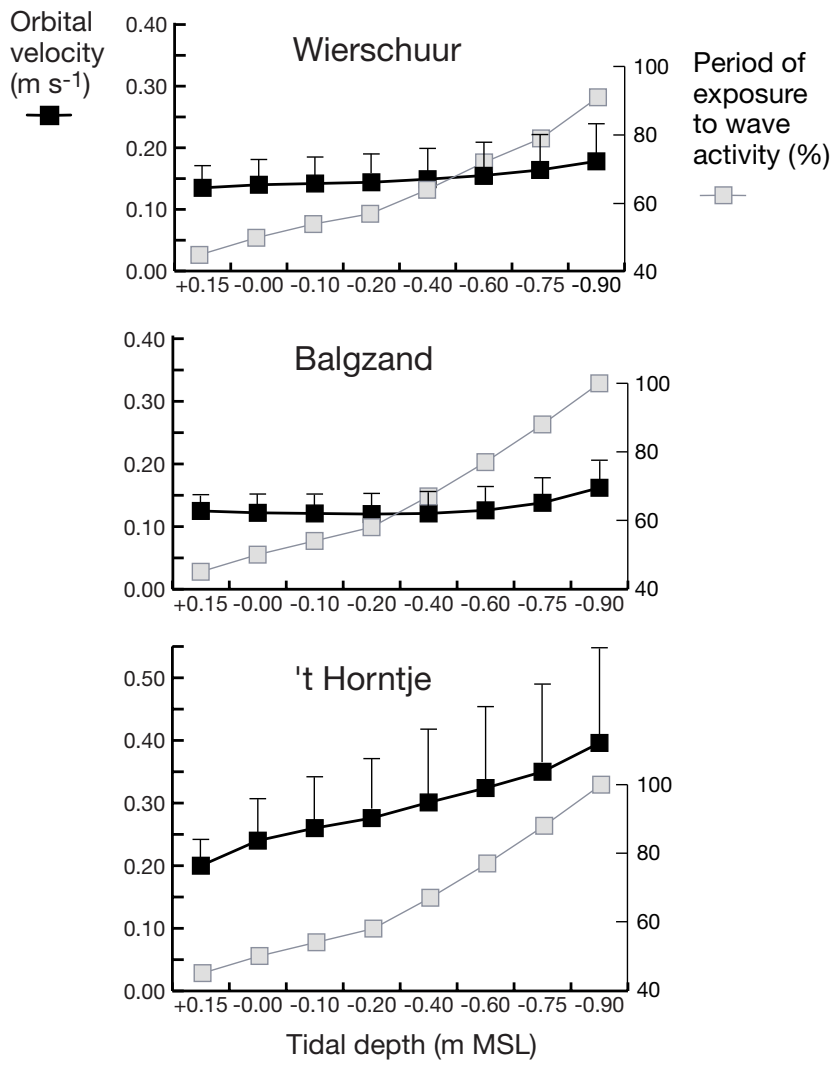

Fig. 3. Tidal depth-related characteristics of the 3 Zostera marina transplantation sites between June 2 and August 31, showing average orbital velocity (mean $+\mathrm{SD}$ ) at sediment surface during tidal cycle on days with fetch of $>0.5 \mathrm{~km}$ (see Table 1), and relative period (\% of time) of exposure to wave action

vegetation at De Plaat. No observations were made of the belowground parts of the plants after disappearance of the aboveground parts, since they might still have been viable and replanting would have diminished the chance of shooting.

Hydrodynamic characteristics. Daily values of the orbital velocity at the sediment surface were calculated for all tidal depths studied, using the effective fetch and wind velocity. Wind direction and velocity data were obtained from the Royal Dutch Meteorological Institute for Station 'De Kooy', which was situated at a distance of 4, 10, 57 and $67 \mathrm{~km}$ from Balgzand, 't Horntje, De Plaat and Wierschuur, respectively. The effective fetch was calculated for each wind direction (rounded to $5^{\circ}$ ) using the Saville formula (Shore Protection Manual: Whalin 1984) of directions from $-30^{\circ}$ to $+30^{\circ}$ in steps of $10^{\circ}$ (see also Keddy 1982). Wave height and wave period were calculated using the Bretscheider method (e.g. Verhagen 1998, and Eqs. [1] \& [2] of present paper), assuming a fetch depth and breaker index of $1.0 \mathrm{~m}$ and 0.5 , respectively, at Wierschuur; $0.8 \mathrm{~m}$ and 0.5 , respectively, at Balgzand; and $10 \mathrm{~m}$ and 0.63 , respectively, at 't Horntje. These values are based on the bathymetry of the surrounding area (Fig. 1): fetch depth is based on the average depth of the fetch area, and the breaker index is 0.5 at gently sloping areas such as Wierschuur and Balgzand, but increases when slopes are steep as at 't Horntje (Verhagen \& van der Wegen 1998, H. J. Verhagen pers. comm.):

$$
\begin{aligned}
& g H_{\mathrm{s}} / u^{2}=0.283 \times \tanh \left[0.530 \times\left(g d / u^{2}\right)^{0.750}\right] \times \\
& \tanh \left\{0.0125 \times\left(g F / u^{2}\right)^{0.42} / \tanh \left[0.530 \times\left(g d / u^{2}\right)^{0.750}\right]\right\} \\
& g T / u=2 \pi \times 1.2 \times \tanh \left[0.833 \times\left(g d / u^{2}\right)^{0.375}\right] \times \\
& \tanh \left\{0.077 \times\left(g F / u^{2}\right)^{0.25} / \tanh \left[0.833 \times\left(g d / u^{2}\right)^{0.375}\right]\right\}
\end{aligned}
$$

where $T=$ wave period (s), $u=$ wind velocity $\left(\mathrm{m} \mathrm{s}^{-1}\right.$ at $10 \mathrm{~m}$ above surface), $d=$ depth (m), $g$ = gravitational accelation, $F=$ fetch $(\mathrm{m})$ and $H_{\mathrm{s}}=$ wave height $(\mathrm{m})$.

At each tidal depth where we transplanted eelgrass, we calculated the horizontal orbital velocity $U$ at the sediment surface from $H_{\mathrm{s}}$ and $T$ using the formula of Visser (as used in the program CRESS: Verhagen \& van der Wegen 1998, and H. J. Verhagen pers. comm.):

$$
U=H_{\mathrm{s}} / 2 \times \omega \times 1 / \sinh (k d)
$$

where $\omega=2 \pi / T, k=2 \pi / L, L=\sqrt{(g d)} \times\left(1-d / L_{0}\right) \times T$, $L_{0}=1.56 T^{2}$.

To calculate the average orbital velocity at the sediment surface per tidal cycle, we used a sinusoidal function to simulate the tidal curves, and calculated $U$ (Eq. 3) at all water levels from +(tidal amplitude) to -(tidal amplitude) in steps of $2 \mathrm{~cm}$ (Eq. 4). In the case of the transplantation sites Balgzand and 't Horntje, the sinusoidal function was flattened at the high-tide levels to simulate the actual tidal curve at these sites by use of the condition 'if water level $>55$ then water level $=55$ '. The maximal orbital velocity was the highest orbital velocity reached during 1 tidal cycle.

$$
U_{\text {average }}=\sum_{i=-(a-1), 2}^{(a-1)}\{U \times[\arcsin ((i+1) / a)-\arcsin ((i-1) / a)] / \pi\}
$$

where $a=$ amplitude $(\mathrm{cm})$ and $i=$ water level $(\mathrm{cm})$.

Statistical analysis. The number of Zostera marina shoots, day of death and percentage of inflorescences were normally distributed, and shoot length was lognormally distributed. The latter was log-transformed prior to analysis, the back-transformed means were used as a central measure, and the standard errors were calculated according to Mood et al. (1974). The effect of tidal gradient (Expts 1 and 3) was tested with repeated-measures analysis of variance (ANOVA) (procedure Mixed: SAS Institute Inc. 1989). Monitoring events involved in the statistical analysis were, in Expt 1: Weeks 4, 7, 9, 11, 14 and 27; in Expt 3: Weeks 1, 2, 4, 6 , and 9 . When the data were similar on several tidal depths (i.e. all plants had disappeared within $2 \mathrm{wk}$ ), 
only results from the greatest depth were included in the analysis. The effect of stabilising the sediment with shell armour on the day of death of the $Z$. marina shoots was tested by ANOVA (general linear model, GLM procedure: SAS Institute Inc. 1989), with Bonferroni correction for testing 4 times, for each tidal depth. Day of death was calculated by averaging the last day that any seagrass plant was present and the first day of its absence. ANOVA and Tukey's test for comparison of means were used to test the percentage of inflorescences and shoot length in Expt 1, the effect of exclosures, shell armour or no treatment on the number of $Z$. marina shoots 4 wk after transplantation at various tidal depths in Expt 2, and the effect of different kinds of exclosures and peg-anchoring on the number of $Z$. marina shoots $4 \mathrm{wk}$ after transplantation in Expt 3.

\section{RESULTS}

\section{Depth gradient and sediment stabilisation}

The transplanted Zostera marina plants were established successfully in the zone between 0.0 and $-0.20 \mathrm{~m}$ MSL at Wierschuur and Balgzand (Expt 1: Fig. 4, repeated-measures ANOVA, $\mathrm{p}<0.001$ for depth, day and depth $\times$ day at both locations, except the effect of day at Wierschuur, where $p<0.05$ ). The low initial losses of transplants at those depths and at the control site indicated a low transplantation stress, although the plants were shorter at the control site relative to the natural vegetation of the donor site. At Wierschuur, transplantation was also successful at +0.15 and $0 \mathrm{~m}$ MSL, in contrast to Balgzand. The absence of sediment stabilisation at depths of $-0.40 \mathrm{~m}$ MSL and deeper resulted in the complete loss of transplants within $2 \mathrm{wk}$. Sediment stabilisation retarded the loss of transplants for a number of weeks, especially at $-0.40 \mathrm{~m}$ MSL (Figs. $5 \& 6, \mathrm{p}<0.001$ at both locations at $-0.40 \mathrm{~m} \mathrm{MSL}$, and $\mathrm{p}<0.01$ at -0.60 at Wierschuur). At the relatively exposed transplantation site ('t Horntje), all eelgrass plants below $0.0 \mathrm{~m}$ MSL disappeared within $1 \mathrm{wk}$, while at +0.15 and $0.0 \mathrm{~m}$ MSL some desiccated plants with dark brown leaves survived for a further 1 to $2 \mathrm{wk}$.

At 't Horntje, the average maximal orbital velocity at the sediment surface during a tidal cycle was between 0.53 and $0.63 \mathrm{~m} \mathrm{~s}^{-1}$ (Table 1), while these values were 0.35 and $0.42 \mathrm{~m} \mathrm{~s}^{-1}$ at Balgzand and Wierschuur, respectively. At Balgzand and Wierschuur, eelgrass transplantations were successful when the relative period of exposure to wave action was lower than ca $60 \%$ (at -0.20 m MSL: Fig. 3).

The relationship between transplantation success and tidal depth was already apparent after 1 wk (Fig. 4). At
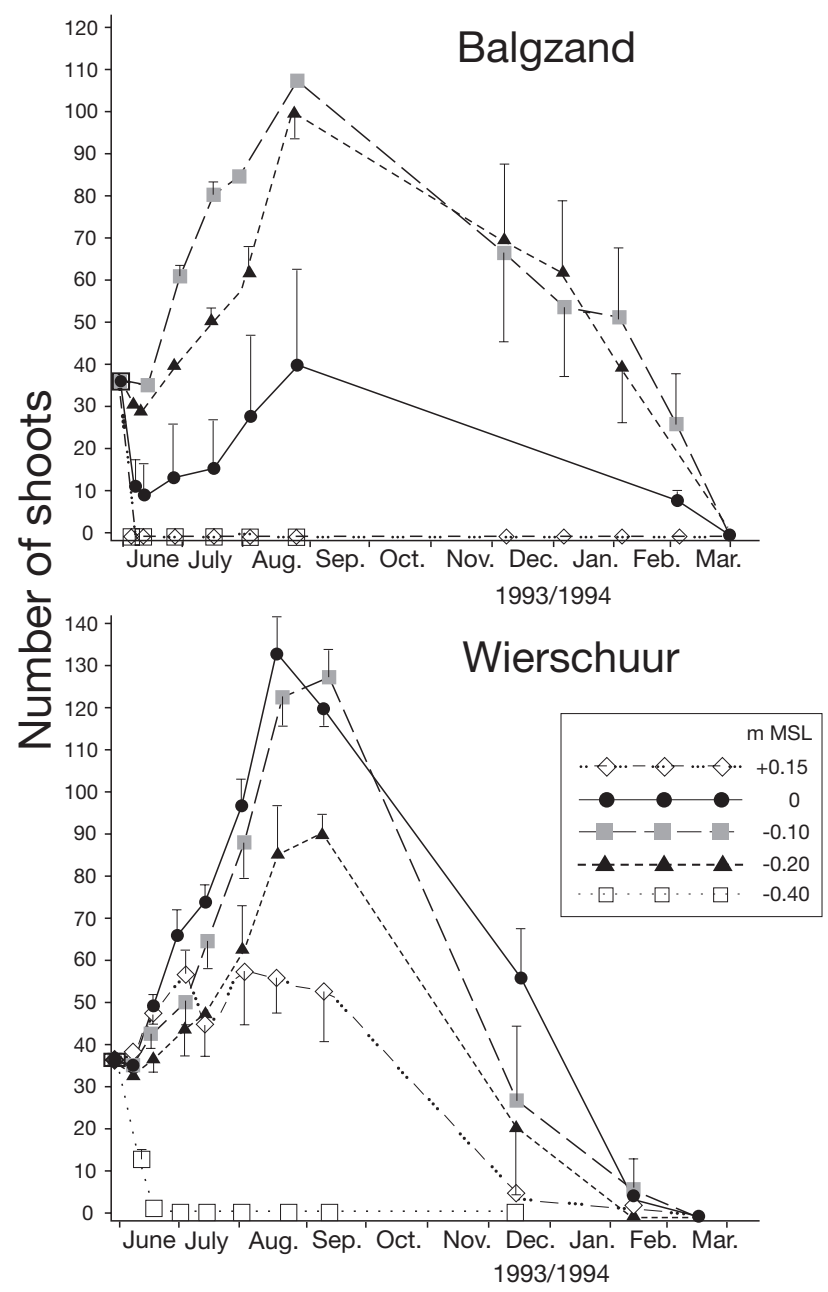

Fig. 4. Zostera marina. Effect of tidal depth on number of shoots in Transplantation Expt 1. Means +SE are presented

Balgzand and Wierschuur, the highest wave action during the first week occurred on the very day of transplantation, with a maximal orbital velocity at the sediment of 0.41 and $0.44 \mathrm{~m} \mathrm{~s}^{-1}$. These maxima occurred at all investigated tidal depths during the tidal cycle. Average orbital velocity increased with depth from $0.14 \mathrm{~m} \mathrm{~s}^{-1}$ at $+0.15 \mathrm{~m} \mathrm{MSL}$ to $0.23 \mathrm{~m} \mathrm{~s}^{-1}$ at $-0.90 \mathrm{~m} \mathrm{MSL}$. Loss of plants occurred at tidal depths where the average orbital velocity at Day 0 was higher than $0.165 \mathrm{~m} \mathrm{~s}^{-1}$. At 't Horntje, the highest wave action occurred on Day 6 , when maximal orbital velocity at the sediment surface varied between $0.59(+0.15 \mathrm{~m} \mathrm{MSL})$ and $0.82 \mathrm{~m} \mathrm{~s}^{-1}$ $(-0.60 \mathrm{~m} \mathrm{MSL})$. The average orbital velocity varied between 0.23 and $0.50 \mathrm{~m} \mathrm{~s}^{-1}$ on Day 6 .

\section{Exclosures}

No losses occurred in the exclosures that reduced water dynamics (Expts 2 and 3, Figs. 6-8), indepen- 


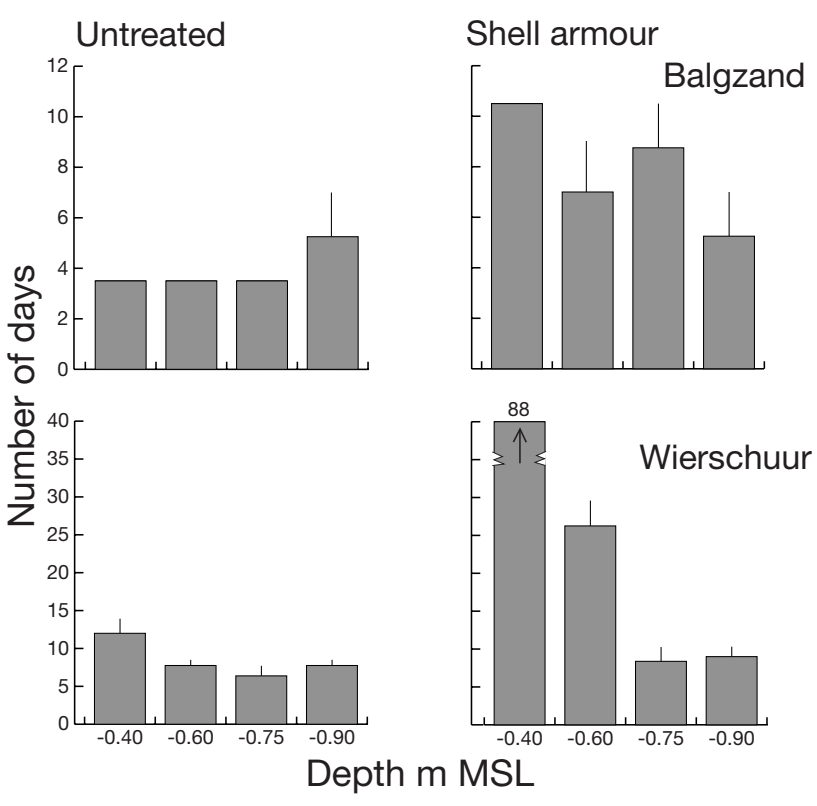

Fig. 5. Zostera marina. Number of days to mortality of transplants in untreated and shell-armoured sediment along depth gradient. Means $+\mathrm{SE}$ are presented

dent of depth (Figs. $6 \& 7$, repeated-measures ANOVA, $\mathrm{p}>0.1$ ). The Zostera marina plants in the exclosures at $-0.60 \mathrm{~m}$ MSL performed better than the plants in the shell-armoured or untreated plots at -0.40 and $-0.60 \mathrm{~m}$ MSL (Tukey's test, $\mathrm{p}<0.05$ ), and even tended to perform better than the exclosure plants at $-0.40 \mathrm{~m}$ MSL (Fig. 6, ANOVA, p < 0.1). At $-0.40 \mathrm{~m}$ MSL, sedimentation in the exclosures was ca $8 \mathrm{~cm} \mathrm{mo}^{-1}$, and ca $5 \mathrm{~cm}$ $\mathrm{mo}^{-1}$ at $-0.60 \mathrm{~m} \mathrm{MSL}$. At $0 \mathrm{~m} \mathrm{MSL}$ no difference between unprotected and exclosures was observed (Fig. 6, Tukey's test, p < 0.05). Anchoring of the eelgrass plants with pegs did not prevent their loss within 2 wk at depths greater than $-0.40 \mathrm{~m}$ (Expt 3: Fig. 7, repeated-measures ANOVA for effect depth, day and depth $\times$ day $=\mathrm{p}<0.001$ ).

In exclosures sealed with gauze, half of the eelgrass shoots had established after 4 wk in the duplicate exclosures (Expt 3: Fig. 8). In exclosures sealed with plexiglass, all plants were still present and healthy after $4 \mathrm{wk}$, whereas in the open exclosures the plants disappeared within $2 \mathrm{wk}$. All differences were statistically significant (Tukey's test, $\mathrm{p}<0.05$ ).

Removal of the exclosures after 1 mo resulted in the complete loss of Zostera marina plants within 2 wk (in both Expts 2 and 3).

\section{Length of Zostera marina shoots}

After $4 \mathrm{wk}$, the transplanted Zostera marina plants (both Wierschuur $0 \mathrm{~m}$ MSL and control site) were shor-

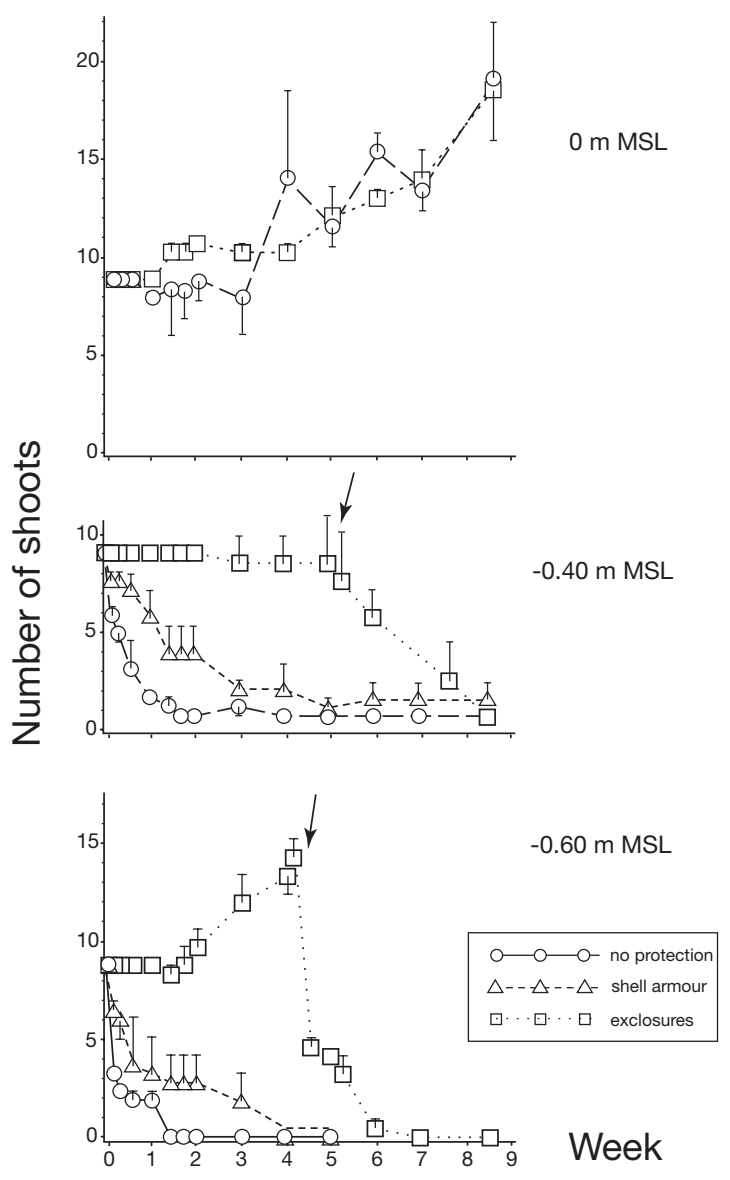

Fig. 6. Zostera marina. Effect of sediment stabilisation (shell armour) and protection from water dynamics (by exclosures with plexiglass tops) on number of shoots (means $+\mathrm{SE}$ ) along depth gradient. Arrows $=$ removal of exclosures

ter than the plants in the natural vegetation (Table 2, ANOVA, $\mathrm{p}<0.05)$. The length of the unprotected $Z$. marina plants, with or without sediment stabilisation, decreased with increasing depth, in contrast to the protected exclosure plants that showed no depthrelated differences in shoot length (Table 2, ANOVA, $\mathrm{p}<0.05)$.

\section{Generative phase, overwintering and germination}

The highest percentage of Zostera marina plants with inflorescences (ca $60 \%$ ) was recorded at the end of August in the $0.0 \mathrm{~m}$ MSL zone, both at the transplantation sites and the donor site. The percentage of inflorescences decreased significantly with increasing depth ( $\mathrm{p}<0.05$ ): from around $60 \%$ at +0.15 and $0.0 \mathrm{~m}$ MSL, to around $40 \%$ at $-0.20 \mathrm{~m} \mathrm{MSL}$ and $0 \%$ at $-0.40 \mathrm{~m}$ MSL. Eelgrass in exclosures with plexiglass coverings formed inflorescences synchronously with plants at higher tidal levels (see also Hermus 1995). 


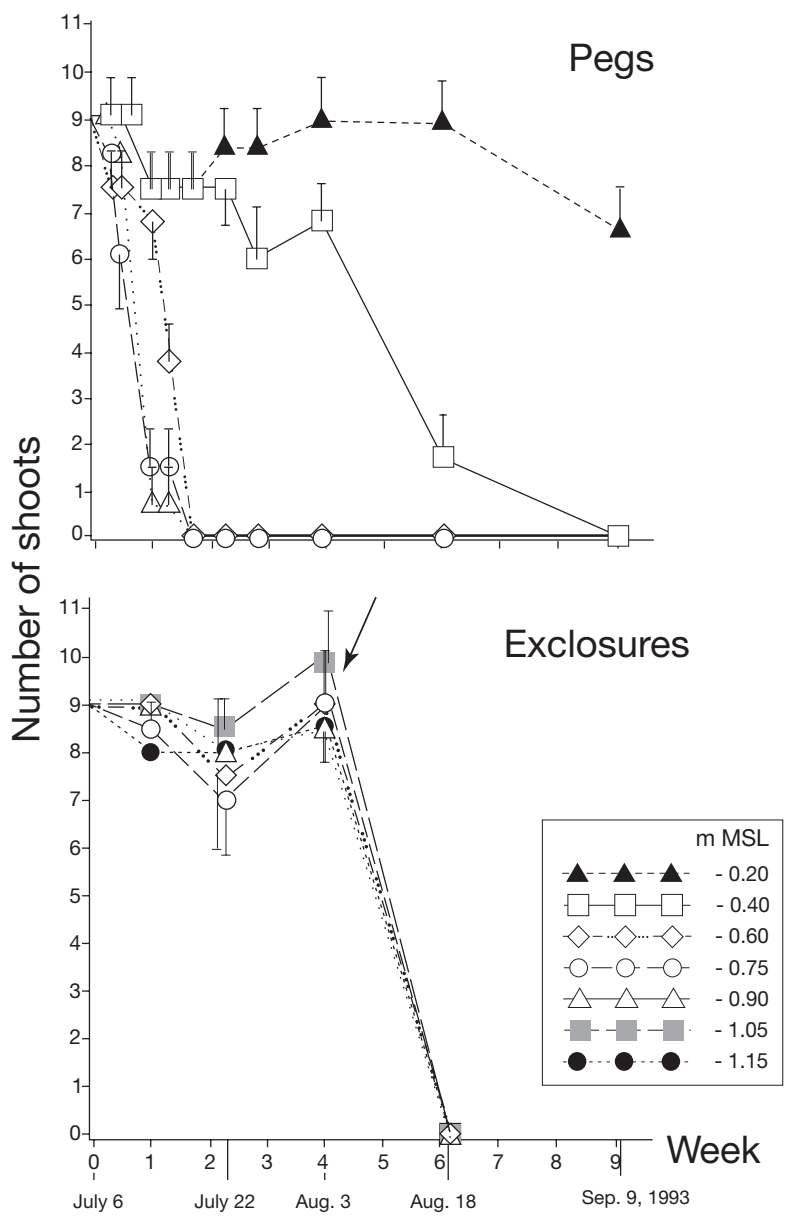

Fig. 7. Zostera marina. Effect of reduced water dynamics (exclosures) and peg-anchoring on number of shoots (means $+\mathrm{SE}$ ) along depth gradient. Arrow $=$ removal of exclosures

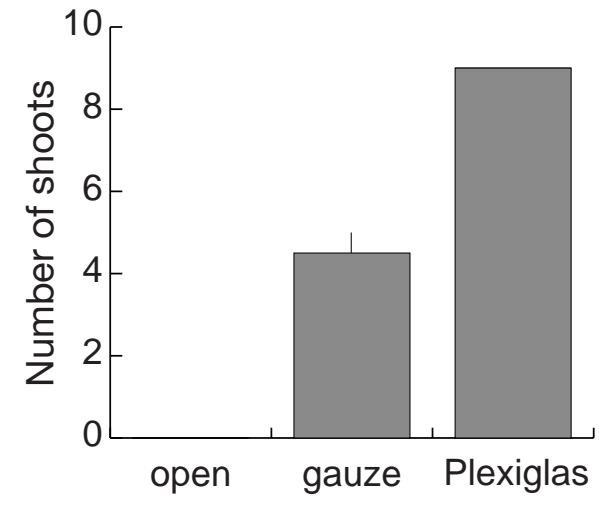

Fig. 8. Zostera marina. Effect of high (open top), intermediate (gauze top) and low (plexiglass top) water dynamics on number of shoots (means $+\mathrm{SE}$ ) in exclosures that excluded large potentially bioturbating organisms after $4 \mathrm{wk}$

seedlings emerged within a few metres of the former eelgrass plots. At Balgzand, 3 seedlings were recorded in February which did not survive the subsequent cold period. At Wierschuur, 87 seedlings were recorded in the period February to May, with maximum numbers in April (66 seedlings), predominantly between 0 and $-0.10 \mathrm{~m}$ MSL. They did not survive. The cotyledons had a very dense epiphyte cover $(50 \%)$ during spring, which was not observed at the donor site. Subsequently, relatively few seeds germinated in June and July and developed into generative plants forming seeds. These disappeared during the following spring.
By the end of November air temperatures had dropped to -1 to $-6^{\circ} \mathrm{C}$, and the tidal flats were covered with ice; nevertheless, many seagrass plants survived (Fig. 4). In February, a second extremely cold period occurred, with day temperatures below $-15^{\circ} \mathrm{C}$ (without ice-cover). The remaining plants were subsequently lost.

At the donor site, a mass appearance of white cotyledons in January 1994 indicated large-scale germination. Most of them seemed able to develop into adult plants during spring, having generative shoots in summer. The seedlings at the control transplantation developed synchronously with seedlings from the natural donor population (Hermus 1995). At the transplantation sites, all Zostera marina
Table 2. Zostera marina. Effect of sediment stabilisation with shells, reduction of water dynamics by exclosures, and transplantation effects on length $(\mathrm{cm})$ of shoots along a depth gradient $5 \mathrm{~d}$ (June 7) and $4 \mathrm{wk}$ (June 29) after transplanting. Data are geometric means (SD); $\mathrm{n}=15$

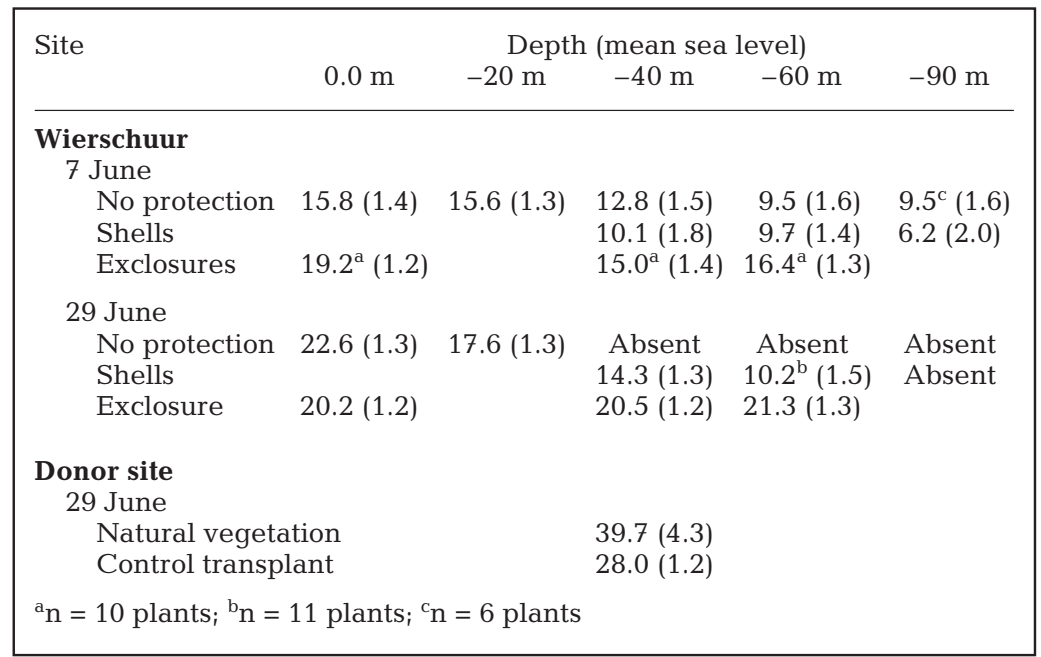




\section{DISCUSSION}

\section{Water dynamics}

No losses of Zostera marina transplantations occurred in exclosures with reduced water dynamics, in contrast to the complete loss of unprotected transplants at depths greater than $-0.20 \mathrm{~m}$ MSL. The failure of plants to establish at deeper sites, where the water dynamics were more severe, and the rapid disappearance of $Z$. marina plants after removal of the exclosures after 1 mo (Watanabe \& Terawaki 1986 found that 1 mo was sufficient to establish), must have been due to the water dynamics being too severe at these depths. No differences were found between the number of $Z$. marina shoots in exclosures along the tidal gradient from -0.60 to $-1.15 \mathrm{~m}$ MSL. Apparently, during the growing season, light availability is still sufficient at a depth of $-1.15 \mathrm{~m}$ MSL and light limitation could not have caused the loss of unprotected seagrass at all depths greater than $-0.20 \mathrm{~m}$ MSL.

Bioturbation, often causing transplantation losses along the eastern and southern shores of the USA (Fonseca et al. 1994, 1998, Davis et al. 1998, Hammerstrom et al. 1998), had no effects on the transplantations in the Dutch Wadden Sea (see 'Introduction'). This was further evidenced by our finding that the plants disappeared also in enclosures without tops ( 0 to $5 \%$ reduced water dynamics, entrance of large animals unlikely and not observed), half of the plants disappeared in exclosures with gauze tops (40 to $50 \%$ reduced water dynamics, no animals larger than $1 \mathrm{~mm}$ could enter), whereas all plants remained in the plexiglass-topped exclosures (80 to $100 \%$ reduced water dynamics). The differences between these 3 treatments were significant.

In exclosures at -0.60 m MSL, Zostera marina tended to perform better than at $-0.40 \mathrm{~m}$ MSL, perhaps because the sedimentation rate was higher in the exclosures at $-0.40 \mathrm{~m}$ MSL. In the latter exclosures, $8 \mathrm{~cm}$ of sediment was deposited in 1 mo compared to $5 \mathrm{~cm}$ in the former. Increased sedimentation is obviously caused by reduced water dynamics in the exclosures.

\section{Depth gradient at 3 transplantation sites}

The successful establishment of Zostera marina transplants at Wierschuur and Balgzand between 0.0 and $-0.20 \mathrm{~m}$ MSL during the growing season showed that these locations met the habitat requirements of the plants; this corresponded to results from a similar experiment conducted at Wierschuur 1 yr earlier (van Katwijk \& Schmitz 1993). Transplantation success was low at higher tidal levels, probably due to bird-forag- ing in this zone (Hermus 1995). All unprotected transplants with or without peg-anchoring disappeared within a few days at $-0.40 \mathrm{~m}$ MSL and deeper. At this tidal depth the plants are exposed to wave action for $60 \%$ of the time. Before their disappearance, the plants were shorter than at higher tidal levels, presumably because they had lost their leaves. At the transplantation site 't Horntje, plants disappeared at all depths, probably due to the higher exposure of this site to water dynamics compared to the other 2 sites. At 't Horntje, maximal orbital velocities at the sediment surface frequently exceeded $0.60 \mathrm{~m} \mathrm{~s}^{-1}$ during the summer months, with the possibility of breaking waves. At Balgzand and Wierschuur, maximal orbital velocities at the sediment surface averaged ca $0.40 \mathrm{~m} \mathrm{~s}^{-1}$ during the first few months after transplantation.

\section{Water dynamics and zonation in natural Zostera marina beds}

In intertidal Zostera marina beds in the Dutch and German Wadden Sea, SW Netherlands, and, for example, in the Thames estuary (not only during present conditions, but also formerly, when subtidal eelgrass was still present and light was not limiting), plant cover diminishes with increasing depth (Harmsen 1936, C. den Hartog pers. comm., authors' pers. obs.). In all cases, except perhaps in the present-day Thames estuary, this could not be attributed to light limitation (Harmsen 1936, Wijgergangs \& de Jong 1999, present study). Our results indicate that, in non-sheltered areas, this can be attributable to increasing water dynamics along the depth gradient. This was supported by the observation that intertidal $Z$. marina beds penetrate to larger depths than usual when shelter is present: e.g. behind a mussel bed at low-tide level in Sylt, Germany (K. Reise pers. comm.); behind the dam encompassing the eelgrass bed at De Plaat, Terschelling at $-0.50 \mathrm{~m}$ MSL (authors' pers. obs.); and directly behind an island at Roscoff, France (C. den Hartog pers. comm.).

A seeming contradiction of our findings is the luxurious growth recorded for Zostera marina around low tide in the Wadden Sea at the beginning of the twentieth century (Harmsen 1936, de Jonge \& Ruiter 1996). At that time, 2 (not necessarily genetically based) morphotypes of $Z$. marina were present: a robust, perennial morphotype, and a flexible (often annual) morphotype (Harmsen 1936). These morphotypes were also described in other parts of the world (Harmsen 1936, Tutin 1938, Keddy \& Patriquin 1978). The morphotype that occurred in the subtidal zone can withstand higher water dynamics because of its robustness and its relatively larger belowground biomass that provides better anchoring. It cannot extend towards 
higher tidal levels because it is more susceptible to desiccation than the flexible type of $Z$. marina that grows in the mid-intertidal zone (Harmsen 1936, Tutin 1938, Keddy \& Patriquin 1978, van Katwijk et al. 2000). With this in mind, our results can explain why nonvegetated zones existed at non-sheltered locations in the Wadden Sea and in the Thames estuary in the 1930s (Harmsen 1936): the water dynamics were too strong for the flexible type of $Z$. marina, and the period of emergence during low tide was too long for the robust type of $Z$. marina.

\section{Sediment stabilisation}

Sediment stabilisation with shells delayed, but did not prevent, the loss of the transplanted plants at $-0.40 \mathrm{~m}$ MSL (and in Wierschuur also at $-0.60 \mathrm{~m} \mathrm{MSL}$ ). The lag varied between 6 and $76 \mathrm{~d}$. At greater depths, no effect of stabilisation by shells was recorded. These results are consistent with previous findings at Wierschuur (van Katwijk \& Schmitz 1993). Furthermore, the previous experiment showed a distinct positive effect of shell stabilisation at $-0.20 \mathrm{~m} \mathrm{MSL}$, whereas no effect was found at 0.0 and $+0.15 \mathrm{~m} \mathrm{MSL}$, perhaps due to a water-draining effect of the shells (larger interstitial spaces in the sediment) causing desiccation of the plants (van Katwijk \& Schmitz 1993). Therefore, the application of shell armour is particularly useful at the lower limit of potential mid-intertidal habitats of Zostera marina.

\section{Generative phase, overwintering and recruitment from seeds}

The transplanted eelgrass plants expanded vegetatively and reached the generative phase in synchrony with the natural vegetation at the donor site (Hermus 1995). The number of Zostera marina plants gradually decreased during autumn, which is the normal period of die-off and is accompanied by dropping temperatures, storms, and ice-cover (den Hartog \& Polderman 1975, D. J. de Jong pers. comm., R. M. Asmus pers. comm., authors' pers. obs.) and grazing by overwintering birds (Jacobs et al. 1981).

At the donor site at De Plaat, an untimely large-scale germination of Zostera marina was observed in January (April is normal), as a result of unusually low salinities (Hootsmans et al. 1987, Hermus 1995) caused by exceptionally high river discharges at this time. Likewise, at Balgzand, the majority of seeds may have germinated in January, with the seedlings being possibly lost during a subsequent severe storm period in February. Unfortunately, the storm period prevented moni- toring to confirm this. At the transplantation site Wierschuur (which is less influenced by freshwater discharges), we frequently noted small numbers of seedlings during February to May that became covered by epiphytes and did not survive, in contrast to the seedlings at the control site and donor site at De Plaat. Therefore, the Wierschuur habitat did not fulfil the requirements for $Z$. marina seedlings during the spring period. However, some seeds did germinate successfully later in the season, and developed into generative plants forming seeds. Apart from the aspects discussed above, the failure of the transplantations to establish from seeds may have been due to the low number of shoots used in our small-scale experiments.

\section{CONCLUSIONS AND RECOMMENDATIONS}

Water dynamics in the Dutch Wadden Sea are often too strong for the establishment and maintenance of intertidal Zostera marina: maximal orbital velocity at the sediment frequently exceeded $0.60 \mathrm{~m} \mathrm{~s}^{-1}$. At sites where the average maximal orbital velocity at the sediment reached ca $40 \mathrm{~m} \mathrm{~s}^{-1}$, transplantation success was depth-related, which was attributable to increasing periods of exposure to water dynamics with increasing depth. Transplantation failed at $-0.40 \mathrm{~m}$ MSL and deeper. This tidal depth corresponds to a period of exposure to wave action of ca $60 \%$ of the time. Neither light limitation nor bioturbation could explain these results. To increase transplantation success of $Z$. marina, a sheltered location is recommended: at a local scale, a stable mussel bed could provide such a shelter (N. Dankers pers. comm.). Also, providing local and temporal shelter with (biodegradable) dam-like structures would provide refugia from where a transplantation could expand. In the Wadden Sea, eelgrass experiments with such stabilising constructions are planned. Sediment stabilisation by shell armour is recommended for the lower depth limit of an eelgrass transplantation. Depth limitation of intertidal Z. marina by water dynamics can explain zonation patterns that occur in natural eelgrass beds in several tidal systems in northwest Europe.

Acknowledgements. This study was financed by the Ministry of Transport, Public Works and Water Management. We thank Professor Dr V. N. de Jonge, Professor Dr C. den Hartog, D. J. de Jong, Dr J. G. M. Roelofs, Professor Dr G. van der Velde and B. Kelleher for useful discussions and comments on the manuscript. Hydraulic information was kindly supplied by Professor H. J. Verhagen of the International Institute for Infrastructural, Hydraulic and Environmental Engineering in Delft. We thank Dr R. M. Asmus, Dr H. Asmus and Professor Dr K. Reise of the Alfred Wegener Institute in Sylt, Germany, for advice. We thank workers of the Ministry of Transport, 
Public Works and Water Management, students of the University of Nijmegen and several volunteers for their efforts in the fieldwork. G. H. W. Schmitz, L. J. M. Wijgergangs and P. H. van Avesaath are thanked for useful consultation and assistance during the research. The Technical Department, the Illustration Service and the Department of Statistical Consultation of University of Nijmegen are thanked for constructing the exclosures, preparing the figures, and providing statistical advice, respectively.

\section{LITERATURE CITED}

Anonymous (1989) Water voor nu en later. Derde Nota Waterhuishouding. Ministry of Transport, Public Works and Water Management. Tweede Kamer 1988-1989 21250, Den Haag

Asmus RM, Asmus H (1991) Mussel beds: limiting or promoting phytoplankton? J Exp Mar Biol Ecol 148:215-232

Boley KE (1988) Morphodynamische Analyse der Wattsüdseite Hallig Hooge. Geographisches Institut der Justus Liebig Universität Giessen, Giessen

Davis RC, Short FT (1997) Restoring eelgrass, Zostera marina L., habitat using a new transplanting technique: the horizontal rhizome method. Aquat Bot 59:1-15

Davis RC, Short FT, Burdick DM (1998) Quantifying the effects of green crab damage to eelgrass transplants. Restor Ecol 6:297-302

de Jonge VN, de Jong DJ (1992) Role of tide, light and fisheries in the decline of Zostera marina L. in the Dutch Wadden Sea. Neth Inst Sea Res Publ Ser 20:161-176

de Jonge VN, Ruiter JF (1996) How subtidal were the 'subtidal beds' of Zostera marina L. before the occurrence of the wasting disease in the early 1930's? Neth J Aquat Ecol 30:99-106

den Hartog C, Polderman PJG (1975) Changes in the seagrass populations of the Dutch Waddenzee. Aquat Bot 1: 141-147

den Hartog C, van der Velde G (1970) De flora en de vegetatie van het Balgzand. Wet Meded K Ned Natuurh Veren 86:20-36

Dijkema KS (1989) Habitats of the Netherlands, German and Danish Wadden Sea. Research Institute for Nature Management, Texel

Dittmann S, Villbrandt M (1999) Size frequency, distribution and colour variation of Carcinus maenas in the Spiekeroog back barrier system. In: Dittmann S (ed) The Wadden Sea ecosystem: stability properties and mechanisms. SpringerVerlag, Berlin, p 163-173

Fonseca MS, Bell SS (1998) Influence of physical setting on seagrass landscapes near Beaufort, North Carolina, USA. Mar Ecol Prog Ser 171:109-121

Fonseca MS, Kenworthy WJ (1987) Effects of current on photosynthesis and distribution of seagrasses. Aquat Bot 27:59-78

Fonseca MS, Kenworthy WT, Courtney FX, Hall MO (1994) Seagrass planting in the southeastern United States: methods for accelerating habitat development. Restor Ecol 2: $198-212$

Fonseca MS, Kenworthy WJ, Thayer GW (1998) Guidelines for the conservation and restoration of seagrasses in the United States and adjacent waters. NOAA Coastal Ocean Program Decision Analysis Series No. 12. NOAA Coastal Ocean Office, Silver Spring, MD

Giesen WBJT, van Katwijk MM, den Hartog C (1990) Eelgrass condition and turbidity in the Dutch Wadden Sea. Aquat Bot 37:71-85
Hammerstrom K, Sheridan P, McMahan G (1998) Potential for seagrass restoration in Galveston Bay, Texas. Tex J Sci 50: $35-50$

Harmsen GW (1936) Systematische Beobachtungen der Nordwest-Europäischen Seegrasformen. Ned Kruidk Archf 46: 852-877

Hermus DCR (1995) Herintroduktie van zeegras in de Waddenzee. Het verloop van de beplantingen in 1992-1994 \& zaadexperimenten. Department Aquatic Ecology and Environmental Biology, University of Nijmegen, Nijmegen

Hootsmans MJM, Vermaat JE, Van Vierssen W (1987) Seedbank development, germination and early seedling survival of two seagrass species from the Netherlands: Zostera marina L and Z. noltii Hornemann. Aquat Bot 28:275-285

Jacobs RPWM, den Hartog C, Braster BF, Carriere FC (1981) Grazing of the seagrass Zostera noltii by birds at Terschelling (Dutch Wadden Sea). Aquat Bot 10:241-259

Keddy PA (1982) Quantifiying within-lake gradients of wave energy: interrelationships of wave energy, substrate particle size and shoreline plants in Axe Lake, Ontario. Aquat Bot 14:41-58

Keddy CJ, Patriquin DG (1978) An annual form of eelgrass in Nova Scotia. Aquat Bot 5:163-170

Koch EW (1999) Preliminary evidence on the interdependent effect of currents and porewater geochemistry on Thalassia testudinum Banks ex König seedlings. Aquat Bot 63: 95-102

Lozán JL, Breckling P, Fonds M, Krog C, van der Veer HW, Witte JI (1994) Über die Bedeutung des Wattenmeeres für die Fischfauna und deren regionale Veränderung. In: Lozán JL, Rachor E, Reise K, von Westernhagen H, Lenz W (eds) Warnsignale aus dem Wattenmeer. Blackwell Wissenschafts-Verlag, Berlin, p 226-234

Mood AM, Graybill FA, Boes DC (1974) Introduction to the theory of statistics. McGraw-Hill, Kogakusha

Oudemans CAJA, Conrad JFW, Maats P, Bouricius LJ (1870) Verslag der Staatscommissie inzake de wiermaayerij. Anonymous Verslag aan den Koning over de Openbare Werken in het Jaar 1869. Van Weelden en Mingelen, Den Haag, p 199-231

Postma H (1961) Transport and accumulation of suspended matter in the Dutch Wadden Sea. Neth J Sea Res 1:148-190

Postma H, Dijkema KS (1982) Hydrography of the Wadden Sea: movements and properties of water and particulate matter. Wadden Sea Working Group, Leiden

Reise K, Herre E, Sturm M (1989) Historical changes in the benthos of the Wadden Sea around the island of Sylt in the North Sea. Helgol Meeresunters 43:417-433

Rijnsdorp AD, van Leeuwen PI, Daan N, Heessen HJL (1996) Changes in abundance of demersal fish species in the North Sea between 1906-1909 and 1990-1995. ICES J Mar Sci 53:1054-1062

SAS Institute Inc. (1989) SAS/STAT user's guide. Version 6. 4th edn. SAS Institute Inc., Cary, NC

Tutin TG (1938) The autecology of Zostera marina in relation to its wasting disease. New Phytol 37:50-71

van der Veer HW, Feller RJ, Weber A, Witte JI (1998) Importance of predation by crustaceans upon bivalve spat in the intertidal zone of the Dutch Wadden Sea as revealed by immunological assays of gut contents. J Exp Mar Biol Ecol 231:139-157

van Katwijk MM (1992) Herintroduktie van zeegras in de Waddenzee. 1. Mesocosmexperimenten met Groot zeegras (Zostera marina L.). Department of Aquatic Ecology and Environmental Biology, University of Nijmegen, Nijmegen

van Katwijk MM (1993) Reintroduction of seagrass (Zostera 
marina L. and Z. noltii Hornem.) in the Dutch Wadden Sea. Wadden Sea Newsl 1993-1:22-25

van Katwijk MM, Schmitz GHW (1993) Herintroduktie van Zeegras in de Waddenzee. Beplantingen 1991 en 1992. Department of Aquatic Ecology and Environmental Biology, University of Nijmegen, Nijmegen

van Katwijk MM, Schmitz GHW, Hanssen LSAM, den Hartog C (1998) Suitability of Zostera marina populations for transplantation to the Wadden Sea as determined by a mesocosm shading experiment. Aquat Bot 60:283-305

van Katwijk MM, Hermus DCR, de Jong DJ, Asmus RM, de Jonge VN (2000) Habitat suitability of the Wadden Sea for restoration of Zostera marina beds. Helgol Mar Res 54: $117-128$

Verhagen HJ (1998) Hydraulic boundary conditions. In: Pilarczyk KW (ed) Dikes and revetments. Design maintenance and safety assessment. AA Balkema, Rotterdam, p 41-74

Editorial responsibility: Otto Kinne (Editor), Oldendorf/Luhe, Germany
Verhagen HJ, van der Wegen M (1998) User manual CRESS; coastal and river engineering support system. In: Pilarczyk KW (ed) Dikes and revetments. Design maintenance and safety assessment. AA Balkema, Rotterdam, p 525-536

Watanabe Y, Terawaki T (1986) Development of techniques for marine macrophyte bed creation in the coastal zone near a power plant: 6. Assessment of a transplanting method to prevent the eelgrass (Zostera marina L.) from being washed away. Denryoku Chuo Kenkyusho Hokoku u86008:i-iii-i1-16 [Abstract]

Whalin RW (1984) Shore protection manual. Army Coastal Engineering Research Center, US Government Printing Office, Washington DC

Wijgergangs LJM, de Jong DJ (1999) Een ecologisch profiel van zeegras en de verspreiding in Nederland. Department of Aquatic Ecology and Environmental Biology, University of Nijmegen, Nijmegen

Submitted: February 24, 2000; Accepted: June 8, 2000 Proofs received from author(s): November 13, 2000 